\title{
Accumulation of biomass and bioenergy in culms of cereals as a factor of straw cutting height**
}

\author{
Tomasz Zajacc, Agnieszka Synowiec ${ }^{2 *}$, Andrzej Oleksy', Jan Macuda ${ }^{4}$, Agnieszka Klimek-Kopyra ${ }^{1}$ \\ and Franciszek Borowiec ${ }^{3}$
}

\author{
${ }^{1}$ Institute of Crop Production, ${ }^{2}$ Department of Agrotechnology and Agricultural Ecology, \\ ${ }^{3}$ Department of Animal Nutrition and Feed Management; University of Agriculture, Al. Mickiewicza 21, 31-120 Cracow, Poland \\ ${ }^{4}$ Faculty of Drilling, Oil and Gas, Department of Oil Engineering, AGH University of Science and Technology, \\ Al. Mickiewicza 30, 30-059 Cracow, Poland
}

Received June 10, 2016; accepted March 10, 2017

A b s t r a c t. Cereal straw is an important biomass source in Europe. This work assessed: 1) the morphological and energetic characteristics of culms of spring and winter cereals, 2) the energy deposited in the different aboveground parts of cereals, 3) losses of energy due to different cutting heights. The straw of winter and spring cereals was collected from arable fields during the seasons 2009/10 and 2010/11 in southern Poland. Detailed biometric measurements of culms and internodes were performed. The losses of straw biomass and energy were assessed during simulation of cutting the culm at different heights, up to $50 \mathrm{~cm}$. Longer and heavier culms were developed by winter wheat and triticale and oat. Cutting of straw up to $10 \mathrm{~cm}$ did not lead to significant losses in straw yield. The total amount of energy in the culms was as follows: triticale $>$ winter wheat $>$ oat $>$ spring wheat $>$ winter barley $>$ spring barley. Cutting the culms above $20 \mathrm{~cm}$ led to significant differences in terms of biomass energy between cereal species. The smallest losses of energy were recorded for spring and winter barley. Oat and barley accumulated the highest energy in grains.

$\mathrm{K}$ e y w o r d s: culm, internode, yielding, harvest index, harvest index energy

\section{INTRODUCTION}

The growing awareness of societies regarding environmental protection has resulted in efforts undertaken to increase the share of renewable energy in the total energy consumption in various countries (Borjesson and Gustavsson, 1996; Gokcol et al., 2009). Saidur et al. (2012) argue that wood and wood wastes, followed by agricultural crops and their by-products, are the most important sources of energy from biomass. Cereal straw and wood biomass are the two major sources of renewable energy in central

*Corresponding author e-mail: a.stoklosa@ur.krakow.pl

**This work was financed by the Ministry of Science and Higher Education of Poland, 3154/DS, year 2009-2011.
Europe (McKendry, 2002a, 2002b), given the large forested areas and a significant acreage of cereals. Demirbas et al. (2009) place straw as the third main source of biomass in Europe. Currently, cereals occupy about $70 \%$ of the arable land in Poland (Statistical Yearbook 2015) and about $54 \%$ of the arable land in the EU-28 (EUROSTAT 2015). With such a large share of cereals in the crop arrangement in Europe, local overproduction of straw is often a consequence. This situation relates mostly to farms where plant production is carried out (cereals) without livestock. In recent years, a majority of cereal straw has been used as both fuel and organic fertiliser (Gauder et al., 2011; Summers et al., 2003). To obtain a full environmental assessment of the production of biomass for energy purposes, assessment of the life cycle should be carried out (Krzyżaniak et al., 2016).

The primary focus of cereal breeders and farmers, since the so-called 'green revolution', has been to improve grain yield per area unit to reduce hunger in the world, as cereal grains have a leading role in the caloric contribution in the human diet. This has been approached by using breeding tools and medium and high-input agricultural practices adapted to local habitats. Genetic breeding is focused on shortening the cereal culm, thus maximizing productivity. Capturing the natural mutation of wheat in Japan, as a gene donor for short straw, and transfer thereof to the United States immediately after the Second World War resulted in the creation of the wheat cultivar 'Norin 10', which has significantly accelerated the process of culm shortening (Reitz

(C) 2017 Institute of Agrophysics, Polish Academy of Sciences 
and Salmon, 1968). From the agro-biological point of view, the spectacular increase in the grain yield was mainly related to the expected response of highly productive and short-culmed cultivars to continually optimised cultivation methods (Austin et al., 1989). The second reason for shortening cereal culms is prevention of lodging, as it leads to reduced quantity and quality of cereal grains (Foulkes et al., 2011). It is believed that the reduced length of the culm, in combination with the increase in the crop and cultivar flexibility, ensures high resistance to lodging in intensive production. Introduction of chemical growth-retardants to agricultural practices effectively limited culm length, which, in turn, improved the resistance of the crop to lodging (Berry et al., 2004; Tripathi et al., 2003). Olumekun (1996) reported that the Cycocel growth retardant (i.e. 2-chloroethyl-trimethylammonium chloride) reduces the length, but does not reduce the weight of the wheat culm. This phenomenon relates to the anatomical effects of retardants, mainly to the simultaneous thickening of the culm and increasing its diameter, while the length of the internodes is shortened (Lowe and Carter, 1972; Sanvicente et al., 1999; Tripathi et al., 2003; Zając 1987). Consequently, straw yield is reduced (Rebetzke et al., 2011).

The amount of cereal stubble depends on the height of straw cutting during harvest, and the amount of energy deposited in this stubble is not known. The quantitative changes in straw yield and in the related amount of energy left in the stubble are a result of varying cutting height at harvesting (Zając et al., 2013b). There are no discernment studies relating to the vertical distribution of biomass in the culms of cereal species and cultivars of both winter and spring forms. Until now, no objective method referring to the accurate distribution of yield and energy in cereal straw has been developed. Our approach, as a scientific novelty, can help to determine precisely straw yield and energy deposited in the stubble, based on cutting height harvest. This work assessed: 1) the morphological and energetic characteristics of culms of different spring and winter cereal species, 2) the energy amount deposited in the different aboveground parts of cereal organs, 3) energy losses due to different cutting heights.

\section{MATERIAL AND METHODS}

Cereal culms were collected from arable fields where growth retardants were not used, in the southern part of Poland (Silesia; $49.7-50.0^{\circ} \mathrm{N}, 18.5-19.1^{\circ} \mathrm{E}$ ) in the vegetative seasons 2009/2010 and 2010/2011. The following cereals were included: spring and winter wheat (Triticum aestivum L.), spring and winter barley (Hordeum sativum Pers.), winter triticale (x Triticosecale Wittm. ex. A. Camus), and oats (Avena sativa $\mathrm{L}$ ). Each of the species was collected before the harvest from 30 different fields and from five different locations within each field, in an area of $1 \mathrm{~m}^{2}$, lined diagonally across the field. For each of the locations, the number of ears per square meter was counted and, subsequently, 10 culms were taken for further analyses. The culms were cut at the ground level. Samples with a minimum of 100 culms per species were chosen for the final measurements and placed in an airy barn for slow drying.

We measured the biometric factors number, length, diameter, and mass of each of the internodes. The diameter was measured in the middle of each internode, using the electronic calliper Yato- $7201^{\circledR}$. In addition, the inflorescence was evaluated, i.e. the length of ears or panicles as well as the mass of seeds per inflorescence. After the measurements, each culm and inflorescence was placed in separate paper bags, which were kept in the dryer for $24 \mathrm{~h}$ at $105^{\circ} \mathrm{C}$. Internode mass and straw yield were calculated based on $15 \%$ water content.

The following parameters were calculated:

- mass density per $1 \mathrm{~cm}^{2}$ (Sanvicente et al., 1999) for each internode;

- harvest index (Zajacc et al., 2013a) as the ratio between grain weight and total dry matter weight;

- harvest index energy (Sinha et al., 1982) accumulated in the straw and grain;

- straw yield $\left(\mathrm{t} \mathrm{ha}^{-1}\right)$ calculated by multiplying the mass of a single culm by the number of culms per $1 \mathrm{~m}^{2}$ and expressed as mass per $1 \mathrm{ha}$; analogical calculation was performed for the accumulation of energy in straw and grains $\left(\mathrm{GJ} \mathrm{ha}^{-1}\right)$;

- loss of straw yield simulated using Excel 2010 and based on the different heights of cutting culms every $2.5 \mathrm{~cm}$ from 0 to $50 \mathrm{~cm}$.

The concentration of energy in the different parts of cereals was determined experimentally by measuring the higher heating value in a calorimeter KL-10 (Precyzja, Bydgoszcz, Poland) at an oxygen pressure of $20 \mathrm{~atm}$, according to the Polish Norm PN-81/G-04513 and ISO 1928. The combusted sample was weighed with a precision of $0.0001 \mathrm{~g}$ and the results were calculated for $1 \mathrm{~g}$.

Based on the calorimeter measurements, the following indicators were calculated:

$U D M$ - energy per unit of dry matter of internode $\left(\mathrm{J} \mathrm{g}^{-1}\right)$, value measured in the calorimeter:

$$
W I=\text { mass of internode } \times U D M,
$$

where: $W I-$ energy per whole internode:

$$
C E=\sum W I_{1}+\ldots+W I_{n},
$$

where: $C E$ - total energy of a whole cereal culm;

$$
\text { SI in } C E=\frac{(W I 100)}{C E},
$$

where: $S I$ in $C E$ is share of energy of single internode in the $C E$.

Due to the different share of culms of different heights noted in both vegetative seasons, the weighted average values were calculated. 
The results were analysed using one-way ANOVA, separately for the analysis of cereal species or vegetative seasons. Significant differences between means were calculated using Tukey test. Regression analysis was performed using the statistical software STATISTICA 10 (StatSoft 2011).

Analysis of weather conditions in the Silesia region during the two consecutive vegetative seasons was carried out based on average air temperatures and total precipitation within a 30 -year period (Table 1).

In the growing season 2009/2010, excessive rainfall was noted in spring (especially in May 2010), which caused local flooding as well as water retention on the surface of flat fields. Also, the cloudiness in May 2010 caused a drop in air temperature. Favourable conditions for cereal growth occurred during the growing season 2010/2011, due to higher air temperatures in the months of April-June. Only July 2011 was cooler due to intensive rainfall $(211.6 \mathrm{~mm})$, causing difficulties in the harvesting of cereals, especially winter barley.

\section{RESULTS}

On average, during the vegetative season 2011, cereals developed longer culms and internodes, compared to the 2010 season (Table 2). This arrangement was determined by the weather conditions in the spring and summer 2011, when lower precipitation and higher air temperatures were noted (Table 1). Higher air temperatures, especially during the generative development, promoted the elongation of internodes and improved the conditions of culms growth. In 2011, the 1st basal internode was significantly longer, heavier and thicker. Internodes 2-5, although longer than in the 2010 season, were significantly lighter and thinner. The highest, 6th internode (peduncle), was also longer in 2011, compared to that in 2010 , but its weight and diameter did not differ between both seasons.

The culms of spring wheat consisted of only five internodes (Table 3). The culms of winter wheat and barley consisted mostly of five internodes, 93 and $84 \%$ of the plants, respectively. The culms of triticale and spring barley were equally composed of both five and six internodes. Oat developed culms with mostly six internodes ( $73 \%$ of plants). As expected, the basal internodes were the shortest, especially the first one, and the peduncle was the longest one. Moreover, in a situation when the culm was composed of more internodes, the first internode was by about $50 \%$ shorter than the basal internode of a culm with a lower number of internodes. The basal internode of oat was significantly shorter than that of the other species and forms. The length of subsequent internodes was increasing, with the exception of spring barley, in which the next but one internode was the longest. The distribution of weight per internode was species-specific. Both forms of wheat as well as oat displayed a linear increase in internode weight, with the highest weight found for the peduncle. Winter and spring barley accumulated the highest biomass in the middle internodes, and winter triticale in the next but one internode. In most of the cereal species, the 2nd or 3rd internodes were the thickest ones, except for spring wheat, where the highest diameter was noted in the 4th internode (the next but one). Compared to the other species, spring barley developed thinner internodes.

T a b l e 1. Weather course during the months of cereal vegetation

\begin{tabular}{|c|c|c|c|c|c|c|c|c|c|c|c|c|}
\hline \multirow{2}{*}{ Year } & \multicolumn{12}{|c|}{ Month } \\
\hline & Jan & Feb & Mar & Apr & May & Jun & Jul & Aug & Sep & Oct & Nov & Dec \\
\hline \multicolumn{13}{|c|}{ Precipitation (mm) } \\
\hline 2009 & - & - & - & - & - & - & - & - & 47.5 & 32.7 & 18.9 & 43.2 \\
\hline 2010 & 64.7 & 44.3 & 32.0 & 71.6 & 410.4 & 135.5 & 157.4 & 176.3 & 105.4 & 24.7 & 46.2 & 79.2 \\
\hline 2011 & 49.4 & 26 & 43.8 & 68 & 128.2 & 133.9 & 211.6 & 95.5 & & & & \\
\hline $\begin{array}{l}1967- \\
2007\end{array}$ & 35.4 & 36.9 & 40.7 & 57.2 & 89.4 & 112.9 & 102.4 & 95.7 & 65.9 & 47.8 & 51.9 & 45.1 \\
\hline \multicolumn{13}{|c|}{ Temperature $\left({ }^{\circ} \mathrm{C}\right)$} \\
\hline 2009 & - & - & - & - & - & - & - & - & 14.2 & 7.6 & 6.2 & -0.6 \\
\hline 2010 & -5.7 & -0.3 & 4.0 & 8.8 & 12.5 & 17.3 & 20.1 & 18.7 & 12.6 & 6.7 & 7.6 & -3.6 \\
\hline 2011 & -0.2 & -2.0 & 4.4 & 10.3 & 14.0 & 18.1 & 17.7 & 19.3 & & & & \\
\hline $\begin{array}{l}1967- \\
2007\end{array}$ & -3.3 & -1.7 & 3.4 & 8.7 & 13.0 & 16.5 & 18.3 & 17.7 & 14.21 & 9.6 & 3.7 & -1.0 \\
\hline
\end{tabular}


T a b l e 2. Comparison of selected characteristics of cereals culms in the vegetative seasons

\begin{tabular}{|c|c|c|c|c|c|c|c|}
\hline \multirow{2}{*}{ Trait } & \multirow{2}{*}{ Year } & \multicolumn{6}{|c|}{ Internodes } \\
\hline & & 1st (basal) & 2nd & $3 \mathrm{rd}$ & 4 th & 5 th & 6th \\
\hline \multirow{2}{*}{ Length $(\mathrm{cm})$} & 2010 & 2.8 & 8.5 & 13.2 & 17.6 & 24.5 & 22.3 \\
\hline & 2011 & 4.3 & 10.2 & 14.6 & 21.3 & 27.8 & 31.3 \\
\hline LSD & & 0.26 & 0.36 & 0.47 & 0.85 & 1.21 & 2.57 \\
\hline $\mathrm{p}^{1}$ & & $* *$ & $* *$ & $* * *$ & $* * *$ & $* * *$ & $* * *$ \\
\hline \multirow{2}{*}{ Weight (g) } & 2010 & 0.057 & 0.170 & 0.246 & 0.297 & 0.314 & 0.171 \\
\hline & 2011 & 0.088 & 0.170 & 0.199 & 0.243 & 0.208 & 0.067 \\
\hline LSD & & 0.007 & NS & 0.013 & 0.018 & 0.020 & 0.029 \\
\hline $\mathrm{p}^{1}$ & & $* * *$ & 1.0 & $* * *$ & $* * *$ & $* *$ & $* * *$ \\
\hline \multirow{2}{*}{$\begin{array}{l}\text { Diameter } \\
(\mathrm{mm})\end{array}$} & 2010 & 3.10 & 3.92 & 4.09 & 3.93 & 3.13 & 2.38 \\
\hline & 2011 & 3.42 & 3.93 & 3.91 & 3.72 & 2.72 & 2.36 \\
\hline LSD & & 0.140 & NS & NS & 0.166 & 0.157 & NS \\
\hline $\mathrm{p}^{1}$ & & $* * *$ & 0.9 & 0.06 & $*$ & $* * *$ & 0.9 \\
\hline
\end{tabular}

$\mathrm{p}^{1}-$ level of significance, $* \mathrm{p}<0.05, * * \mathrm{p}<0.01, * * * \mathrm{p}<0.001$.

Generally, the longer the internode, the lower the biomass (Table 4). The biomass of 1-cm-long fragments of the culm differed significantly among the tested cereals. The share of each internode in the total culm mass of cereals relates to their length, but the correlation was not linear. The highest share in the total culm biomass for triticale, spring wheat, and spring barley had the next but one internode. In the case of winter wheat, winter barley, and oat, two internodes, the highest ones (peduncle) for wheat and oat and the 3rd and 4th in the case of barley, had the highest share in the biomass of their culms.

All tested cereals differed significantly in terms of culm length and weight (Table 5). In general, the winter cereals developed significantly longer and heavier culms than the spring ones, with the longest and heaviest culm being that of winter wheat and the shortest and lightest that of spring barley. In the vegetative season 2011, the culms of cereals were significantly longer, but lighter, compared to the previous year. Inflorescences were both longer and heavier in the vegetative season 2011.

The tested cereals had a different number of shoots per unit area, but this did not influence the final yield of grain or straw, i.e. spring barley developed the highest shoot density and, at the same time, had the lowest grain and straw yields (Table 6). The cereals yielded higher in the vegeta- tive season 2011, when the agrometeorological conditions were more favourable than in the cooler and wetter season 2010. Both forms of barley, spring and winter, as well as oat had the highest values of the harvest index (HI) of all the cereals tested. On the contrary, HI of both forms of wheat, spring and winter, were lower due to the high yield of straw.

The cutting height of cereal straw at harvest determined the amount of losses in straw yield (Fig. 1). The cereals, regardless of the species, were characterised by a similar reaction to cutting. Low cutting, up to $10 \mathrm{~cm}$, did not lead to significant losses in straw yield. Higher and visible losses in straw yield, within both forms of the cereals, i.e. spring and winter, occurred when the cutting height exceeded $20 \mathrm{~cm}$. The increase in the cutting height up to $25 \mathrm{~cm}$ or more resulted in significant differences in straw yield losses between the cereal species.

Increased cutting height of winter wheat culms caused greater losses in straw yield, which for this cereal reached about $0.1 \mathrm{t} \mathrm{ha}^{-1}$ per each $1 \mathrm{~cm}$ of stubble left in the field. Among the spring cereals, oat was the most sensitive species, responding to increased cutting height with significant straw yield losses per unit area. Both forms of barley showed the lowest biomass losses with increased amounts of stubble left in the field. 
T a b l e 3. Comparison of the morphological characteristics of cereal species culms, including groups of different numbers of internodes

\begin{tabular}{|c|c|c|c|c|c|c|c|c|c|c|c|c|}
\hline \multirow{3}{*}{ Internodes } & \multicolumn{6}{|c|}{ Winter species } & \multicolumn{6}{|c|}{ Spring species } \\
\hline & \multicolumn{2}{|c|}{ Wheat } & \multicolumn{2}{|c|}{ Barley } & \multicolumn{2}{|c|}{ Triticale } & \multicolumn{2}{|c|}{ Wheat } & \multicolumn{2}{|c|}{ Barley } & \multicolumn{2}{|c|}{ Oat } \\
\hline & 7.3 & 92.7 & 84.3 & 15.7 & 55.5 & 44.5 & 100.0 & 0.0 & 50.0 & 50.0 & 27.3 & 72.7 \\
\hline \multicolumn{13}{|c|}{ Length $(\mathrm{cm})$} \\
\hline 1st (basal) & 6.2 & 3.3 & 4.4 & 1.7 & 4.8 & 2.7 & 4.0 & - & 4.7 & 2.5 & 4.3 & 1.7 \\
\hline $2 n d$ & 12.5 & 9.9 & 11.9 & 8.4 & 9.7 & 8.2 & 9.0 & - & 11.4 & 8.0 & 9.5 & 6.1 \\
\hline $3 \mathrm{rd}$ & 24.0 & 16.1 & 16.8 & 14.7 & 13.7 & 10.6 & 14.4 & - & 14.8 & 10.2 & 13.9 & 9.9 \\
\hline 4 th & 38.1 & 25.6 & 21.8 & 17.2 & 22.7 & 13.8 & 21.6 & - & 20.7 & 10.5 & 18.1 & 11.5 \\
\hline 5 th & - & 34.5 & 28.5 & 20.8 & 29.3 & 23.2 & 30.7 & - & 18.8 & 12.8 & 35.4 & 17.8 \\
\hline 6 th & - & - & - & 25.2 & - & 27.0 & - & - & - & 11.7 & - & 32.3 \\
\hline$\Sigma$ & 80.8 & 89.4 & 83.4 & 88.0 & 80.3 & 85.5 & 79.7 & - & 70.4 & 55.7 & 81.1 & 79.3 \\
\hline \multicolumn{13}{|c|}{ Weight (g) } \\
\hline 1st (basal) & 0.142 & 0.072 & 0.094 & 0.052 & 0.134 & 0.079 & 0.060 & - & 0.057 & 0.037 & 0.084 & 0.044 \\
\hline $2 \mathrm{nd}$ & 0.245 & 0.218 & 0.209 & 0.215 & 0.222 & 0.216 & 0.133 & - & 0.113 & 0.101 & 0.151 & 0.124 \\
\hline $3 \mathrm{rd}$ & 0.362 & 0.313 & 0.233 & 0.331 & 0.277 & 0.240 & 0.197 & - & 0.116 & 0.123 & 0.205 & 0.190 \\
\hline 4 th & 0.368 & 0.413 & 0.232 & 0.321 & 0.378 & 0.281 & 0.292 & - & 0.121 & 0.119 & 0.238 & 0.209 \\
\hline 5 th & - & 0.379 & 0.176 & 0.313 & 0.286 & 0.349 & 0.294 & - & 0.079 & 0.127 & 0.330 & 0.292 \\
\hline 6 th & - & - & - & 0.232 & - & 0.240 & - & - & - & 0.094 & - & 0.391 \\
\hline$\Sigma$ & 1.116 & 1.395 & 0.944 & 1.464 & 1.297 & 1.405 & 0.976 & - & 0.486 & 0.601 & 1.009 & 1.251 \\
\hline \multicolumn{13}{|c|}{ Diameter (mm) } \\
\hline 1st (basal) & - & 3.21 & 3.64 & 3.44 & 4.12 & 3.79 & 2.88 & - & 2.82 & 2.67 & 3.49 & 3.08 \\
\hline 2 nd & - & 3.74 & 4.29 & 6.04 & 4.76 & 4.50 & 3.40 & - & 3.34 & 3.19 & 4.04 & 4.01 \\
\hline $3 \mathrm{rd}$ & - & 3.97 & 4.28 & 5.13 & 4.93 & 4.77 & 3.42 & - & 3.16 & 3.18 & 3.95 & 4.32 \\
\hline 4th & - & 3.84 & 3.99 & 4.69 & 4.47 & 4.74 & 3.46 & - & 2.92 & 3.09 & 3.56 & 4.11 \\
\hline 5 th & - & 2.69 & 2.60 & 4.12 & 2.72 & 4.07 & 2.62 & - & 2.07 & 2.82 & 3.07 & 3.73 \\
\hline 6 th & - & - & - & 2.55 & - & 2.38 & - & - & - & 1.81 & - & 2.73 \\
\hline
\end{tabular}

The total accumulation of bioenergy in the whole internodes $(W I)$ as well as per $1 \mathrm{~g}$ of dry weight $(U D W)$ of the compared cereals is given in Table 7 . Winter cereals accumulated more energy in the individual internodes than the spring cereals, especially barley. In winter wheat and triticale, the fourth internode was the most abundant in energy. Oat accumulated the highest amount of energy in the highest internode, the peduncle, which was exceptional within the compared species. The accumulation of energy in $1 \mathrm{~g}$ of dry matter $\left(\mathrm{kJ} \mathrm{g}^{-1}\right)$ in the particular internodes was gene- rally insignificant. The relative share of individual internode energy in the total energy of culms was arranged in a similar way as for biomass (Table 4).

In the cooler and wetter season 2010, the 3 rd to 5 th internodes were more abundant in energy (Table 8). The accumulation of energy per $1 \mathrm{~g}$ of dry matter $\left(\mathrm{kJ} \mathrm{g}^{-1}\right)$ in each of the internodes was insignificant between the vegetative seasons. A slightly higher energy was deposited in the 1st internode. The relative contribution of energy of the successive internodes in the total energy of the culm differed 
T a b l e 4. Dry weight per unit length $(1 \mathrm{~cm})$ of straw of cereals and the estimated share of each of internodes in the total culm weight (the average of both vegetation seasons)

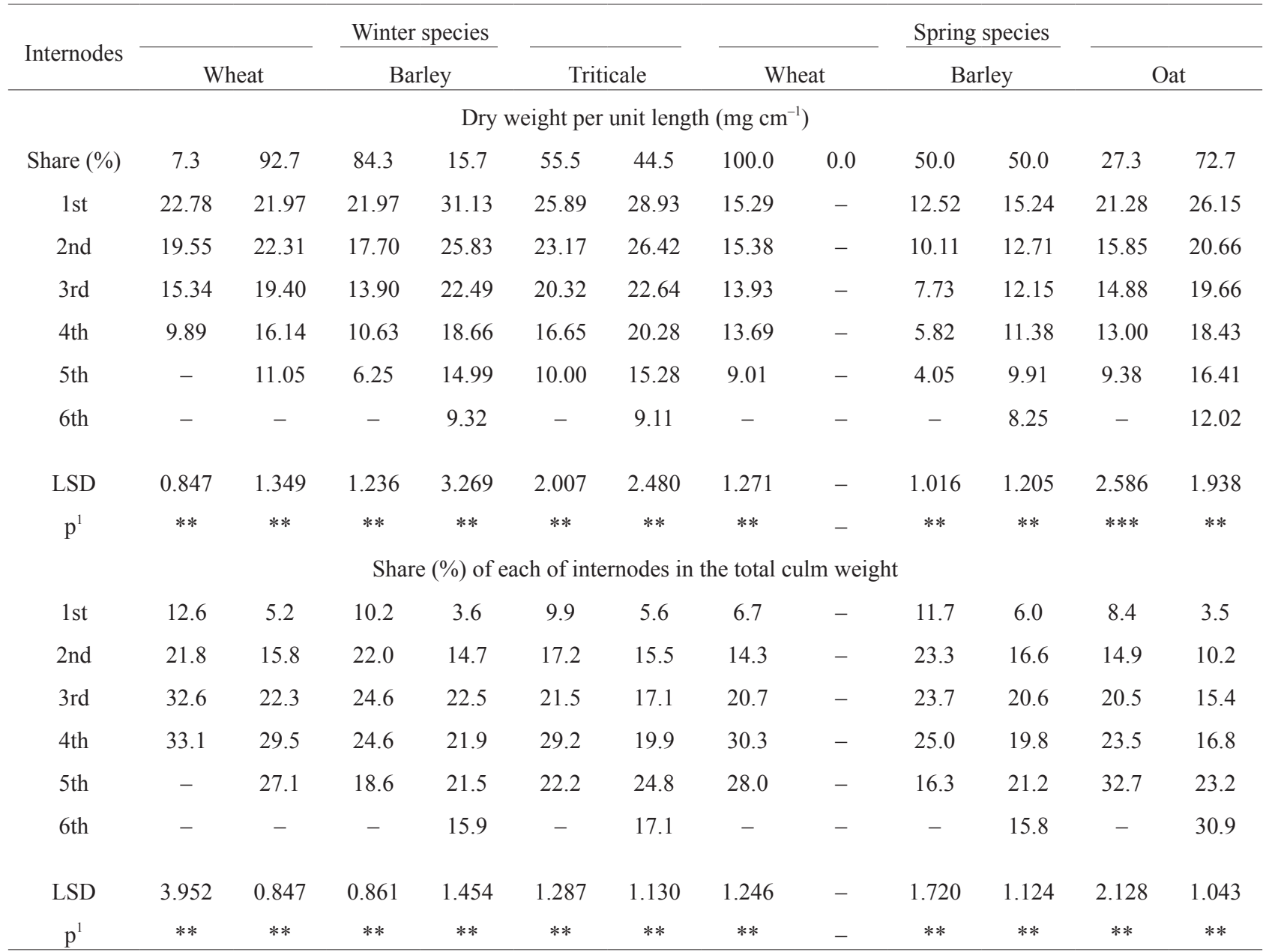

Explanations as in Table 2 .

between the vegetative seasons. More energy was accumulated in the three basal internodes (1st to 3rd) in the 2011 season, compared to 2010. However, in the 2010 season, significantly more energy was accumulated in the upper, 5 th and 6th, internodes.

Winter barley and spring wheat accumulated average amounts of energy in the culms; at the same time, the amount of energy accumulated in their culms was lower than in oat (Table 9). The lowest amount of energy in the culm was accumulated by spring barley, which has the shortest culm, as discussed earlier.

Among all the cereals tested, the highest amount of energy accumulated in the grain was found for oat and triticale. Both forms of wheat stored similar amounts of energy in the grain. Triticale and both forms of wheat, winter and spring, accumulated reasonable amounts of energy in the rachis and the chaffs. The energy accumulated in the culms, rachis, and chaffs was the highest in triticale. The other species can be ranked as follows: winter wheat $>$ oat $>$ spring wheat $>$ winter barley $>$ spring barley. Hereby, the significantly lower accumulation of energy in the culm and rachis of spring barley is interesting.
All the species tested accumulated lower amounts of energy in the straw yield per ha, compared to the grain yield (Table 10). Winter wheat accumulated the highest amount of energy of straw per ha, surpassing the other cereals in this respect. Three species, namely triticale, oat and spring wheat, accumulated similar amounts of energy in the straw per ha, whereas both forms of barley accumulated the lowest energy amounts.

Two species, namely oat and triticale, accumulated the highest amounts of energy in the grain yield per ha. Both forms of wheat accumulated a similar amount of energy in the grain per ha, despite their significantly different yields (Table 6). Non-hulled wheat and triticale cereals accumulated higher amounts of energy in the rachis, chaffs, and hulls; however, one can expect that the fraction of chaff and, especially, hulls will be lost in combined harvesting. It is worth emphasising that the non-hulled cereals accumulated more energy in the straw biomass, including culms, rachis, and chaffs. These relations were arranged 
T a b l e 5. Comparison of length and weight of components of the single culm of cereal

\begin{tabular}{|c|c|c|c|c|c|c|c|}
\hline \multirow[b]{2}{*}{ Species } & \multicolumn{3}{|c|}{ Lenght $(\mathrm{cm})$} & \multicolumn{4}{|c|}{ Weight (g) } \\
\hline & Culm & $\begin{array}{c}\text { Ear or } \\
\text { panicle }\end{array}$ & Shoot & Culm & $\begin{array}{c}\text { Ear or } \\
\text { panicle }\end{array}$ & Grain & Shoot \\
\hline Winter wheat & 88.7 & 8.6 & 97.3 & 1.38 & 1.66 & 1.34 & 3.03 \\
\hline Winter barley & 84.1 & 11.9 & 96.0 & 1.03 & 1.69 & 1.47 & 2.71 \\
\hline Triticale & 82.6 & 9.9 & 92.6 & 1.35 & 2.31 & 1.83 & 3.65 \\
\hline Spring wheat & 79.7 & 8.4 & 88.1 & 0.98 & 1.63 & 1.32 & 2.61 \\
\hline Spring barley & 63.1 & 7.2 & 74.9 & 0.54 & 1.00 & 0.89 & 1.55 \\
\hline Oat & 79.8 & 15.4 & 95.2 & 1.19 & 1.73 & 1.56 & 2.92 \\
\hline LSD & 1.94 & 0.72 & 2.49 & 0.079 & 0.128 & 0.107 & 0.188 \\
\hline $\mathrm{p}^{1}$ & $* *$ & $* *$ & $* *$ & $* *$ & $* *$ & $* *$ & $* *$ \\
\hline 2010 & 76.6 & 8.6 & 85.2 & 1.20 & 1.62 & 1.36 & 2.82 \\
\hline 2011 & 82.7 & 11.8 & 96.1 & 0.95 & 1.71 & 1.44 & 2.67 \\
\hline LSD & 1.59 & 0.53 & 1.65 & 0.060 & NS & 0.075 & 0.145 \\
\hline $\mathrm{p}^{1}$ & $* * *$ & $* *$ & $* *$ & $* * *$ & 0.05 & $*$ & $*$ \\
\hline
\end{tabular}

Explanations as in Table 2.

T a b l e 6. Density of cereals shoots per area, including the share of selected yield components and the harvest index

\begin{tabular}{|c|c|c|c|c|c|c|}
\hline \multirow{3}{*}{ Species } & \multirow{3}{*}{$\begin{array}{l}\text { Shoot density } \\
\quad\left(\mathrm{pcs} \mathrm{m}^{2}\right)\end{array}$} & \multicolumn{2}{|c|}{ Yield } & \multirow{2}{*}{$\begin{array}{c}\text { Grain and straw } \\
\text { biomas }\end{array}$} & \multirow{2}{*}{$\begin{array}{l}\text { Total aboveground } \\
\text { biomas }\end{array}$} & \multirow{3}{*}{ Harvest index } \\
\hline & & grain & straw & & & \\
\hline & & \multicolumn{4}{|c|}{$\left(\mathrm{t} \mathrm{ha}^{-1}\right)$} & \\
\hline Winter wheat & 484 & 6.44 & 6.65 & 13.1 & 14.6 & 0.44 \\
\hline Winter barley & 415 & 6.08 & 4.27 & 10.4 & 11.3 & 0.54 \\
\hline Triticale & 388 & 7.05 & 5.21 & 12.3 & 14.1 & 0.50 \\
\hline Spring wheat & 491 & 6.48 & 4.82 & 11.3 & 12.8 & 0.51 \\
\hline Spring barley & 577 & 5.37 & 3.11 & 8.5 & 9.1 & 0.57 \\
\hline Oat & 440 & 6.83 & 5.19 & 12.0 & 12.8 & 0.53 \\
\hline LSD & 15.1 & 0.51 & 0.35 & 0.76 & 0.84 & 0.016 \\
\hline $\mathrm{p}^{1}$ & $* *$ & $* * *$ & $* *$ & $* *$ & $* *$ & $* *$ \\
\hline 2010 & 436 & 5.90 & 5.24 & 11.1 & 12.3 & 0.48 \\
\hline 2011 & 495 & 6.85 & 4.52 & 11.4 & 12.6 & 0.55 \\
\hline LSD & 12.0 & 0.29 & 0.26 & NS & NS & 0.010 \\
\hline$p^{1}$ & $* *$ & $* * *$ & $* * *$ & 0.36 & 0.28 & $* *$ \\
\hline
\end{tabular}

Explanations as in Table 2. 

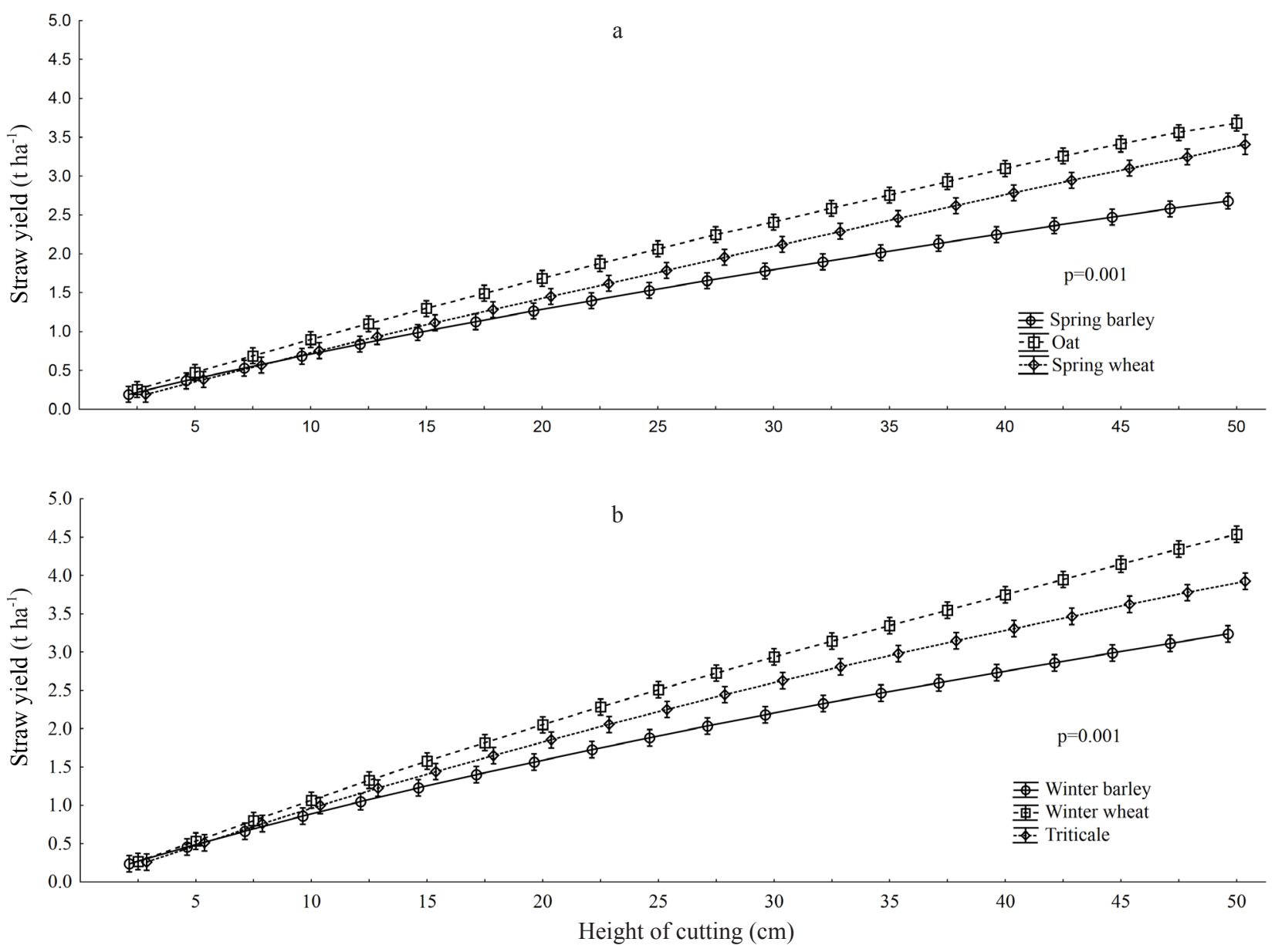

Fig. 1. Effect of the cutting height at the harvest time of: $a$ - spring and $b$ - winter cereals on the losses of straw yield $\left(t\right.$ ha $\left.{ }^{-1}\right)$.

differently for hulled cereals, such as oat and barley, which accumulated most of the energy in the grains. This pattern is also confirmed by the energy index values.

Winter wheat, triticale, and oat accumulated the highest amounts of energy in the aboveground biomass. In contrast, in the spring and winter barley, the amounts of energy accumulated in the aboveground biomass were the lowest. During both vegetation seasons and under different weather conditions, the different fractions of the energy yield accumulated in the grain or straw showed significant differences, but the total yield of energy accumulated in the aboveground biomass was similar.

The increase in the straw cutting height of more than 20 $\mathrm{cm}$ at harvesting led to visible differences between cereal species, which were similarly arranged in the case of spring wheat and oats (Fig. 2). Significantly lower losses of energy were noted for both spring and winter barley, which is also expressed by the high harvest index value of this species (Table 6).

\section{DISCUSSION}

In this work, we presented a detailed study of accumulation of biomass and energy in the internodes and whole culms of different species of both winter and spring cereals growing in the temperate climate of southern Poland. Up to now, there have been no other studies comparing the differences in section mass of culms of cereals in central Europe. In field experiments, straw yield is usually expressed in values of biomass per hectare, which changes as the cereal grows (Summers et al., 2003) and depends on a variety of factors, i.e. mineral fertilisation (Jarosch et al., 2008) or application of growth regulators (Rajala and PeltonenSainio, 2001).

We have found that the basic number of internodes in the culms of each of the cereal species is five, except for oat culms, which consist mainly of six internodes. Biometric measurements showed that the upper internode, the peduncle, is the longest one in all tested cereals, except barley. Agro-climatic conditions during the two growing seasons 2010-2011 significantly determined the length, weight, 
T a b l e 7. Comparison of accumulation of energy in the whole internodes (WI) and per unit of dry matter (UDM) and the share of energy of individual internode in the total energy of a whole cereal culm $(S I$ in $C E)$

\begin{tabular}{|c|c|c|c|c|c|c|c|c|c|c|c|c|}
\hline \multirow{2}{*}{ Internodes } & \multicolumn{6}{|c|}{ Winter species } & \multicolumn{6}{|c|}{ Spring species } \\
\hline & \multicolumn{2}{|c|}{ Wheat } & \multicolumn{2}{|c|}{ Barley } & \multicolumn{2}{|c|}{ Triticale } & \multicolumn{2}{|c|}{ Wheat } & \multicolumn{2}{|c|}{ Barley } & \multicolumn{2}{|c|}{ Oat } \\
\hline \multicolumn{13}{|c|}{$U D M\left(\mathrm{~kJ} \mathrm{~g}^{-1}\right)$} \\
\hline Share $(\%)$ & 7.3 & 92.7 & 84.3 & 15.7 & 55.5 & 44.5 & 100 & 0.0 & 50.0 & 50.0 & 27.3 & 72.7 \\
\hline $1 \mathrm{st}$ & 18.24 & 18.33 & 17.74 & 17.60 & 17.73 & 17.77 & 18.07 & - & 18.63 & 18.61 & 18.33 & 17.61 \\
\hline $2 \mathrm{nd}$ & 16.27 & 17.05 & 16.65 & 17.71 & 17.80 & 17.88 & 17.38 & - & 18.35 & 16.82 & 16.17 & 16.80 \\
\hline $3 \mathrm{rd}$ & 17.70 & 17.58 & 17.97 & 17.30 & 17.79 & 17.79 & 18.38 & - & 17.01 & 16.09 & 19.25 & 17.37 \\
\hline 4th & 16.99 & 17.70 & 16.57 & 17.01 & 16.87 & 16.70 & 18.46 & - & 17.13 & 17.69 & 16.09 & 16.23 \\
\hline 5 th & - & 17.56 & 17.07 & 17.77 & 17.86 & 17.87 & 18.31 & - & 19.21 & 16.26 & 16.40 & 16.61 \\
\hline 6 th & - & - & - & 16.65 & - & 18.11 & - & - & - & 17.97 & - & 16.88 \\
\hline LSD & & 0.12 & 0.16 & & 0.08 & 0.08 & 0.13 & & & & & 0.21 \\
\hline $\mathrm{p}^{1}$ & & $* *$ & $* *$ & & $* *$ & $* *$ & $* *$ & & & & & $* *$ \\
\hline \multicolumn{13}{|c|}{$W I(\mathrm{~kJ})$} \\
\hline $1 \mathrm{st}$ & 2.83 & 1.31 & 1.67 & 0.92 & 2.37 & 1.41 & 1.08 & - & 1.06 & 0.68 & 1.58 & 0.78 \\
\hline $2 \mathrm{nd}$ & 4.08 & 3.72 & 3.50 & 3.81 & 3.96 & 3.87 & 2.33 & - & 2.07 & 1.70 & 2.49 & 2.07 \\
\hline $3 \mathrm{rd}$ & 6.54 & 5.49 & 4.17 & 5.72 & 4.93 & 4.27 & 3.63 & - & 1.97 & 1.99 & 4.02 & 3.28 \\
\hline 4 th & 6.26 & 7.33 & 3.86 & 5.46 & 6.37 & 4.71 & 5.37 & - & 2.08 & 2.10 & 3.88 & 3.38 \\
\hline 5 th & - & 6.67 & 3.03 & 5.56 & 5.12 & 6.24 & 5.36 & - & 1.52 & 2.06 & 5.49 & 4.84 \\
\hline 6 th & - & - & - & 3.86 & - & 4.35 & - & - & - & 1.70 & - & 6.58 \\
\hline LSD & 0.97 & 0.40 & 0.32 & 0.62 & 0.47 & 0.50 & 0.44 & & 0.24 & 0.17 & 0.64 & 0.42 \\
\hline $\mathrm{p}^{1}$ & $* * *$ & $* *$ & $* *$ & $* *$ & $* *$ & $* *$ & $* *$ & & $* *$ & $* *$ & $* *$ & $* *$ \\
\hline \multicolumn{13}{|c|}{$S I$ in $C E(\%)$} \\
\hline $1 \mathrm{st}$ & 14.4 & 5.4 & 10.5 & 3.6 & 10.1 & 5.7 & 6.7 & - & 12.2 & 6.5 & 9.1 & 3.7 \\
\hline $2 \mathrm{nd}$ & 20.6 & 15.3 & 21.4 & 14.9 & 17.5 & 15.7 & 13.6 & - & 23.9 & 16.4 & 14.3 & 10.1 \\
\hline $3 r d$ & 33.3 & 22.4 & 25.8 & 22.3 & 21.8 & 17.2 & 21.0 & - & 22.5 & 19.4 & 23.2 & 15.9 \\
\hline 4 th & 31.7 & 29.7 & 23.8 & 21.5 & 28.1 & 18.8 & 30.8 & - & 23.9 & 20.6 & 22.1 & 16.2 \\
\hline 5 th & - & 27.2 & 18.5 & 22.3 & 22.6 & 25.1 & 28.1 & - & 17.5 & 20.3 & 31.3 & 23.0 \\
\hline 6 th & - & - & - & 15.5 & - & 17.5 & - & - & - & 16.7 & - & 31.0 \\
\hline LSD & 3.98 & 0.84 & 0.90 & 1.21 & 1.31 & 1.16 & 1.21 & & 1.77 & 1.14 & 2.15 & 1.13 \\
\hline $\mathrm{p}^{1}$ & $* * *$ & $* *$ & $* *$ & $* *$ & $* *$ & $* *$ & $* *$ & & $* *$ & $* *$ & $* *$ & $* *$ \\
\hline
\end{tabular}

Explanations as in Table 2.

and diameter of individual internodes. During the warmer season in 2011, the mass and diameter of the upper internodes ( 3 rd to 6 th) were reduced, whereas the inflorescences were both longer and heavier. So far, such detailed measurements of the length of internodes have been undertaken to analyse the impact of growth retardants on the formation of cereal culms and have shown that the expected reduction in culm length was a result of shortening the length of individual lower internodes from the 2 nd to the 4 th one (Savicente et al., 1999; Tripathi et al., 2003).
On average, winter wheat had the longest culms and spring wheat and spring barley the shortest ones. Fufa et al. (2005) points out a decreasing trend in the length of wheat straw in the last decades. Austin et al. (1989) assessed, using multiple regression analysis, that in the last 150 years of wheat growing, straw yield decreased by about $21 \%$ as a result of culm shortening (by $46 \%$ ), whereas the grain yield increased by about $59 \%$. The deposition of assimilates within plants favours grain yield, due to the relocation of assimilated carbon in the winter wheat from culm to ear (Bell and Incoll, 1990). 
T a b l e 8. Impact of the growing seasons on the accumulation of energy in the whole internodes (WI), per unit of dry matter of each internode $(U D M)$ and the share of individual internodes in the total energy of a single culm of the average cereal $(S I$ in $C E)$

\begin{tabular}{|c|c|c|c|c|c|c|c|}
\hline \multirow{2}{*}{ Indicators } & \multirow{2}{*}{ Years } & \multicolumn{6}{|c|}{ Internodes } \\
\hline & & 1st (basal) & 2 nd & $3 \mathrm{rd}$ & 4th & 5th & 6th \\
\hline \multirow{2}{*}{$U D M\left(\mathrm{~kJ} \mathrm{~g}^{-1}\right)$} & 2010 & 17.94 & 17.57 & 17.24 & 17.46 & 17.39 & 17.63 \\
\hline & 2011 & 18.14 & 16.84 & 18.09 & 16.92 & 17.67 & 17.02 \\
\hline \multirow{4}{*}{$W I(\mathrm{~kJ})$} & LSD & 0.06 & 0.12 & 0.11 & 0.12 & 0.13 & 0.22 \\
\hline & $\mathrm{p}^{1}$ & $* * *$ & $* *$ & $* *$ & $* *$ & $* * *$ & $* * *$ \\
\hline & 2010 & 1.02 & 2.99 & 4.28 & 5.24 & 5.52 & 4.48 \\
\hline & 2011 & 1.59 & 2.87 & 3.61 & 4.10 & 3.71 & 4.50 \\
\hline \multirow{6}{*}{$S I$ in $C E(\%)$} & LSD & 0.13 & NS & 0.24 & 0.33 & 0.35 & NS \\
\hline & $p^{1}$ & $* *$ & 0.159 & $* * *$ & $* * *$ & $* *$ & 0.961 \\
\hline & 2010 & 5.0 & 14.6 & 20.2 & 24.4 & 25.5 & 10.3 \\
\hline & 2011 & 9.9 & 17.9 & 22.4 & 25.1 & 21.3 & 3.4 \\
\hline & LSD & 0.57 & 0.70 & 0.63 & NS & 0.99 & 1.66 \\
\hline & $p^{1}$ & $* *$ & $* *$ & $* * *$ & 0.09 & $* * *$ & $* * *$ \\
\hline
\end{tabular}

Explanations as in Table 2.

In this study, the mass of $1 \mathrm{~cm}$ long straw sections was the highest in the lower parts of the culm. Winter cereals, as well as oat, were characterised by a higher mass of straw sections, compared to that of spring wheat and spring barley. Studies of Summers et al. (2003) showed that the increase in the weight of cereal culm corresponds to the higher yield and lower stand density. However, the lack of understanding of the detailed distribution of biomass in the internodes prevents precise estimation of straw losses left in the field as stubble. In Canada (Alberta), Dassanayake and Kumar (2012) estimated the maximum straw yield of new cultivars of triticale at the level of $4.95 \mathrm{Mg} \mathrm{ha}^{-1}$, but agreed on a net straw yield of $2.43 \mathrm{Mg} \mathrm{ha}^{-1}$, due to several important sources of biomass losses: field (3\%), handling $(5 \%)$, and storage $(10 \%)$. They estimated that the amount of straw harvestable by machines is about $75 \%$, whereas the remaining straw is retained for soil conservation as stubble. Stubble can serve as a source of organic matter for soil and is later transformed into humus. O'Leary and Connor (1997) found that untilled stubble increased soil water storage by $27 \mathrm{~mm}$ in only one year and that the additional water, stored due to stubble retention, was located at a depth of up to $2 \mathrm{~m}$ in the soil profile. Stubble left in the field as a 'cereal prairie' is also important for birds (Delgado and Moreira, 2002). According to McKenzie et al. (2011), cereal stubbles are a foraging habitat for overwintering granivorous farmland bird species. In this light, leaving high stubble in the field may provide a niche for beneficial animals and facilitate agro-biodiversity.
Our study has demonstrated that a substantial increase in the height of culm cutting ( $25 \mathrm{~cm}$ or higher) results in significant losses of straw yield, which can be logically expected, although this was proved in an objective manner in this study.

In general, each internode per culm accumulated a similar amount of energy per $1 \mathrm{~g}$ of dry matter $\left(\mathrm{J} \mathrm{g}^{-1}\right)$. This information is particularly useful as it indicates the uniformity of straw biomass as a source of bioenergy. Both forms of wheat accumulated similar amounts of energy in the grain, despite the significantly different grain yields. This could be attributed to the different chemical compositions of grains of spring and winter wheat, especially in terms of protein content. Wheat and triticale accumulated reasonable amounts of energy in rachis, chaffs, and hulls. However, one can expect that the fractions of chaffs and hulls will be lost during combined harvesting.

\section{CONCLUSIONS}

1. The basic number of internodes per culms of cereals grown in the temperate climate of Poland is five. Winter cereals, especially wheat and triticale, develop longer and heavier culms. Among spring cereals, only oat has long, massive culms. Winter cereals and oat are characterised by a greater mass of $1 \mathrm{~cm}$ - segments of straw.

2. Low straw cutting height, up to $10 \mathrm{~cm}$, does not lead to significant losses in straw yield. A systematic increase in the cutting height of winter wheat straw causes estimated straw losses of about $0.1 \mathrm{t} \mathrm{ha}^{-1}$ for each of $1 \mathrm{~cm}$ of stubble left on the field. 
T a b l e 9. Comparison of the energy accumulated $(\mathrm{kJ})$ in the culms, grain, rachis and chaffs, as well as in the total aboveground biomass of cereal species, including the vegetative seasons

\begin{tabular}{|c|c|c|c|c|c|c|}
\hline Species & Internodes & Culm & Grain & Rachis + chaff & $\begin{array}{l}\text { Culm }+ \text { rachis }+ \\
\text { chaff }\end{array}$ & $\begin{array}{c}\text { Total } \\
\text { aboveground } \\
\text { biomass }\end{array}$ \\
\hline \multirow{2}{*}{ Winter wheat } & low $4(5)$ & 19.70 & 19.46 & 5.54 & 25.24 & 44.70 \\
\hline & high $5(6)$ & 24.52 & 21.97 & 5.54 & 30.06 & 52.03 \\
\hline \multicolumn{2}{|c|}{ LSD and $\mathrm{p}^{1}$ for low and high } & $4.20^{*}$ & NS & NS & NS & NS \\
\hline \multirow{2}{*}{ Winter barley } & low 5 & 16.23 & 24.25 & 3.44 & 19.67 & 43.91 \\
\hline & high 6 & 25.33 & 24.48 & 4.42 & 29.75 & 54.23 \\
\hline \multicolumn{2}{|c|}{ LSD and $\mathrm{p}^{1}$ for low and high } & $2.36^{* * *}$ & NS & $0.41 * * *$ & $2.68^{* * *}$ & $4.49^{* * *}$ \\
\hline \multirow{2}{*}{ Triticale } & low 5 & 22.74 & 29.41 & 7.78 & 30.52 & 59.94 \\
\hline & high 6 & 24.84 & 30.43 & 8.46 & 33.30 & 63.73 \\
\hline \multicolumn{2}{|c|}{ LSD and $\mathrm{p}^{1}$ for low and high } & $2.05^{*}$ & NS & NS & NS & NS \\
\hline Spring wheat & high 5 (6) & 17.77 & 21.55 & 4.97 & 22.74 & 44.28 \\
\hline \multirow{2}{*}{ Spring barley } & low 5 & 8.69 & 18.20 & 1.91 & 10.60 & 28.80 \\
\hline & high 6 & 10.23 & 12.39 & 1.77 & 11.99 & 24.39 \\
\hline \multicolumn{2}{|c|}{ LSD and $\mathrm{p}^{1}$ for low and high } & $0.83^{* * *}$ & $1.24 * * *$ & NS & $0.91 * *$ & $1.94 * * *$ \\
\hline \multirow{2}{*}{ Oat } & low 5 & 17.46 & 27.09 & 3.06 & 20.52 & 47.61 \\
\hline & high 6 & 20.93 & 30.94 & 2.81 & 23.75 & 54.69 \\
\hline \multicolumn{2}{|c|}{ LSD and $\mathrm{p}^{1}$ for low and high } & $2.33^{* *}$ & NS & NS & $2.60^{*}$ & $6.32 *$ \\
\hline \multirow{2}{*}{$\begin{array}{l}\text { LSD and } p^{1} \text { for } \\
\text { species }\end{array}$} & low 5 & $2.51 * *$ & $3.85^{* * *}$ & $1.04 * *$ & $3.26^{* *}$ & $6.51^{* *}$ \\
\hline & high 6 & $2.20^{* *}$ & $2.86^{* *}$ & $0.61^{* *}$ & $2.67 * *$ & $5.21 * *$ \\
\hline \multicolumn{2}{|l|}{2010} & 21.03 & 23.86 & 4.38 & 25.41 & 49.27 \\
\hline \multicolumn{2}{|l|}{2011} & 16.57 & 23.72 & 4.60 & 21.17 & 44.89 \\
\hline \multicolumn{2}{|c|}{ LSD and $p^{1}$ for year } & $1.05^{* * *}$ & NS & NS & $1.37^{* * *}$ & $2.49^{* * *}$ \\
\hline
\end{tabular}

Explanations as in Table 2.

3. The accumulation of energy $\left(\mathrm{J} \mathrm{g}^{-1}\right)$ in the dry weight of each internode per culm is similar, which indicates the energetic homogeneity of cereal straw.

4. The total amount of energy in the culms, rachis, and chaffs is as follows: triticale $>$ winter wheat $>$ oat $>$ spring wheat $>$ winter barley $>$ spring barley.

5. Increasing culm cutting height to above $20 \mathrm{~cm}$ leads to significant differences in the amounts of wasted energy between cereals. The smallest energy losses due to cutting height can be observed for spring and winter barley.

Conflict of interest: The Authors do not declare conflict of interest.

\section{REFERENCES}

Austin R.B., Ford M.A., and Morgan C.L., 1989. Genetic improvement in the field of winter wheat: a further evaluation. J. Agric. Sci., 112, 295-301.

Bell C.J. and Incoll L.D., 1990. The redistribution of assimilate in field-grown winter wheat. J. Exp. Botany, 41, 949-960.

Berry P.M., Sterling M., Spink J.H., Baker C.J., SylvesterBradley R., Mooney S.J., Tams A.R., and Ennos A.R., 2004. Understanding and reducing lodging in cereals. Advances in Agronomy, 84, 217-271.

Borjesson P. and Gustavsson L., 1996. Regional production and utilization of biomass in Sweden. Energy, 21, 747-764.

Dassanayake G.D.M. and Kumar A., 2012. Techno-economic assessment of triticale straw for power generation. Applied Energy, 98, 236-245. 
T a b l e 10. Accumulation of energy in the particular parts of the yield of cereal species per unit area $\left(\mathrm{GJ}^{\mathrm{J}} \mathrm{ha}^{-1}\right)$ and in different vegetative seasons

\begin{tabular}{llccccc}
\hline Species & Internodes & Culm & Grain & Rachis + chaff & $\begin{array}{c}\text { Culm }+ \text { rachis }+ \\
\text { chaff }\end{array}$ & $\begin{array}{c}\text { Total } \\
\text { aboveground } \\
\text { biomass }\end{array}$ \\
\hline Winter wheat & 116.8 & 105.2 & 26.8 & 143.6 & 248.8 & 0.42 \\
Winter barley & 73.4 & 100.7 & 14.9 & 88.3 & 189.0 & 0.54 \\
Triticale & 91.6 & 115.3 & 30.8 & 122.5 & 237.7 & 0.48 \\
Spring wheat & 85.7 & 105.4 & 24.1 & 109.9 & 215.3 & 0.49 \\
Spring barley & 53.6 & 91.9 & 10.7 & 64.3 & 156.3 & 0.57 \\
Oat & 87.5 & 130.5 & 12.7 & 100.2 & 230.8 & 0.56 \\
& & & & & & \\
LSD & 6.07 & 8.65 & 1.67 & 7.28 & 14.67 & 0.015 \\
$\mathrm{p}^{1}$ & $* *$ & $* *$ & $* *$ & $* *$ & $* *$ & $* *$ \\
2010 & 91.8 & 103.2 & 19.2 & 111.1 & 214.3 & 0.48 \\
2011 & 77.8 & 113.1 & 20.8 & 98.7 & 211.8 & 0.54 \\
& & & & & & \\
LSD & 4.43 & 5.26 & 1.50 & 5.61 & NS & 0.011 \\
$\mathrm{p}^{1}$ & $* * *$ & $* * *$ & $*$ & $* * *$ & 0.6 & $* *$ \\
\hline
\end{tabular}

Explanations as in Table 2.
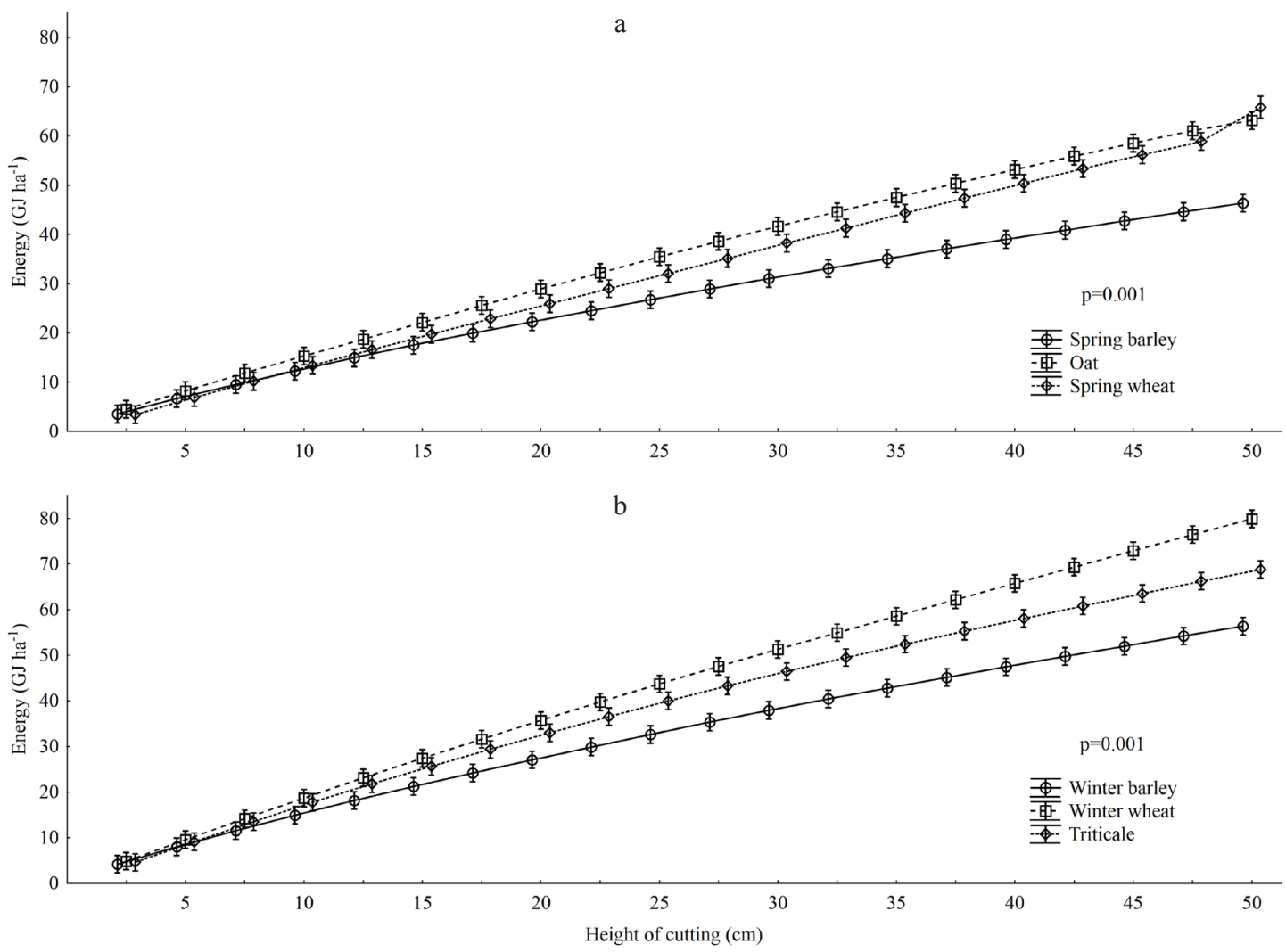

Fig. 2. Effect of the cutting height at the harvest time of: $a$ - spring and b - winter cereals on the losses of bioenergy accumulated in the straw $\left(\mathrm{GJ} \mathrm{ha}^{-1}\right)$. 
Delgado A. and Moreira F., 2002. Do wheat, barley and oats provide similar habitat and food resources for birds in cereal steppes? Agric., Ecosystems Environ., 93, 441-446.

Demirbas M.F., Balat M., and Balat H., 2009. Potential contribution of biomass to the sustainable energy development. Energy Conversion Manag., 50, 1746-1760.

EUROSTAT, 2016. http://epp.eurostat.ec.europa.eu/

Foulkes M.J., Slafer G.A., Davies W.J., Berry P.M., SylvesterBradley R., Martre P., Calderini D.F., Griffiths S., and Reynolds M.P., 2011. Raising yield potential of wheat. III. Optimizing partitioning to grain while maintaining lodging resistance. J. Exp. Botany, 62, 469-486.

Fufa H., Baenziger P.S., Beecher B.S., Graybosch R.A., Eskridge K.M., and Nelson L.A., 2005. Genetic improvement trends in agronomic performances and end-use quality characteristics among hard red winter wheat cultivars in Nebraska. Euphytica, 144, 187-198.

Gauder M., Graeff-Hönninger S., and Claupein W., 2011. Identifying the regional straw potential for energetic use on the basis of statistical information. biomass and bioenergy, 35(5), 1646-1654.

Gokcol C., Dursan B., Alboyaci B., and Sunan E., 2009. Importance of biomass energy as alternative to other sources in Turkey. Energy Policy, 37, 424-431.

Jarosch A.M., Neumann E., Oltmanns M., and Raupp J., 2008. Yield and arbuscular myccorhiza fungal root colonization of organically or minerally fertilized wheat grown on a dry, sandy soil. Proc. 17th Int. Symp. of CIEC, Plant Nutrient Management Under Stress Conditions, November 24-27, Cairo, Egypt.

Krzyżaniak M., Stolarski M.J., Szczukowski S., and Tworkowski J., 2016. Life cycle assessment of new willow cultivars grown as feedstock for integrated biorefineries. BioEnergy Res., 9, 224-238.

Lowe L.B. and Carter O.G., 1972. The influence of CCC (2 chloroethyltrimethylammonium chloride) and temperature on dry matter and assimilate accumulation in wheat. Australian J. Agric. Res., 23, 573-583.

McKendry P., 2002a. Energy production from biomass (part 1): overview of biomass. Biores. Technol., 83, 37-46.

McKendry P., 2002b. Energy production from biomass (part 2): conversion technologies. Biores. Technol., 83, 47-54.

McKenzie A.J., Vickery J.A., Leifert C., Shotton P., and Whittingham M.J., 2011. Disentangling the effects of fertilisers and pesticides on winter stubble use by farmland birds. Basic Applied Ecology, 12, 80-88.

O'Leary G.J. and Connor D.J., 1997. Stubble retention and tillage in a semi-arid environment: 1 . Soil water accumulation during fallow. Field Crop Res., 52, 209-219.
Olumekun V.O., 1996. An analysis of the response of winter wheat (Triticum aestivum) components to Cycocel (chlormequat) application. J. Agronomy Crop Sci., 176, 145-150.

Rajala A. and Peltonen-Sainio P., 2001. Plant growth regulator effects on spring cereal root and shoot growth. Agronomy J., 93, 936-943.

Rebetzke G.J., Ellis M.H., Bonnett D.G., Condon A.G., Falk D., and Richards R.A., 2011. The Rht 13 dwarfing gene reduces peduncle length and plant height to increase grain number and yield of wheat. Field Crop Res., 124, 323-331.

Reitz L.P. and Salmon S.C., 1968. Origin, History, and Use of Norin 10 in Wheat. Crop Sci., 8, 686-689.

Saidur R., Boroumandjazi G., Mekhilef S., and Mohammed H.A., 2012. A review on energy analysis of biomass based fuels. Renewable Sust. Energy Review, 16, 1217-1222.

Sanvicente P., Lazarevitch S., Blouet A., and Guckert A., 1999. Morphological and anatomical modification in winter barley culm after late plant growth regulator treatment. Eur. J. Agronomy, 11, 45-51.

Sinha S.K., Bhargava S.C., and Goel A., 1982. Energy as the basis of harvest index. J. Agric. Science, 99, 237-238.

Statistical Yearbook of the Republic of Poland, 2015. http://aurl. $\mathrm{pl} /$ Yearbook-2015

StatSoft Inc. STATISTICA (data analysis software system), version 10. 2011; www.statsoft.com.

Summers M.D., Jenkins B.M., Hyde P.R., Williams J.F., Mutters R.G., Scardacci S.C., and Hair M.W., 2003. Biomass production and allocation in rice with implications for straw harvesting and utilization. Biomass Bioenergy, 24, 163-173.

Tripathi S.C., Sayre K.D., Kaul J.N., and Narang R.S., 2003. Growth and morphology of spring wheat (Triticum aestivum L.) culms and their association with lodging: effect of genotypes, $\mathrm{N}$ levels and etephon. Field Crop Res., 84, 271-290.

Zając T., 1987. The effect of selected retardants and nitrogen fertilization on the yield and quality of grain of winter rye as well as the increase in density of red clover sown into the rye (in Polish). Acta Agraria et Silvestris, ser. Agraria, 26, 179-191.

Zając T., Kulig B., Oleksy A., Stokłosa A., Pyziak K., and Styrc N., 2013a. Development and yield of morphologically different groups of winter oilseed rape canopy II. The harvest index value depending on the cutting height. Acta Scientiarum Polonorum, ser. Agricultura, 12(1), 57-64.

Zając T., Oleksy A., Stokłosa A., Klimek-Kopyra A., and Macuda J., 2013b. Vertical distribution of dry mass in cereals straw and its loss during harvesting. Int. Agrophys., 27, 89-95. 